\title{
BERKARYA DI MASA PANDEMI: DONGENG BERBAHASA \\ INGGRIS UNTUK MENINGKATKAN LITERASI BUDAYA \\ DAN KEWARGAAN \\ ${ }^{1)}$ Wiwit Sariasih, ${ }^{2)}$ Latifah, ${ }^{3)}$ Geni Kurniati, dan ${ }^{4}$ Christy Tisnawijaya \\ ${ }_{1,2,3,4}$ Dosen Sastra Inggris Universitas Pamulang \\ christy.tisnawijaya@gmail.com
}

\begin{abstract}
ABSTRAK
Taman Pendidikan AlQuran (TPA) memiliki beragam kegiatan keagamaan dan umum seperti baca tulis AlQuran dan olah raga. Akan tetapi, kegiatan tersebut dinilai masih kurang memadai dan kurang spesifik dalam menyampaikan dan melatih literasi budaya dan kewargaan. Dengan demikian, diperlukan kegiatan pembelajaran yang dapat memenuhi kekosongan tersebut. Sebagai solusi, kegiatan mendongeng dinilai dapat menjadi media efektif untuk pembelajaran literasi budaya dan kewargaan bagi siswa. Mendongeng dapat menjadi kegiatan alternatif untuk menstimulasi kreativitas untuk berkarya baik bagi tenaga pendidik maupun siswa pada masa pandemi. Pemilihan tema dongeng yang mengusung pentingnya nilai kebersihan juga menjadi signifikan bagi siswa. Kegiatan PkM ini diikuti oleh peserta didik dari usia TK dan SD kelas 1-3. Dari analisis terhadap hasil kegiatan PkM, peserta didik dapat mengikuti kegiatan dengan serius dan bersemangat, dapat memperagakan cara mendongeng dengan baik, dan juga dapat mempraktikkan cara membersihkan wajah dan tangan terutama dimasa pandemi COVID-19.
\end{abstract}

Kata Kunci: COVID-19, literasi budaya dan kewargaan, mendongeng, PkM, siswa TPA

\begin{abstract}
AlQuran Education Park (TPA) has a variety of religious and public activities such as reading and writing the AlQuran, including sports. However, these activities are still considered inadequate and less specific in instilling cultural and citizenship literacy. Thus, additional learning activities can fulfil this need. As a solution, storytelling is an effective medium for students' cultural and citizenship literacy. Storytelling can be an alternative activity to stimulate creativity to work for both educators and students during the pandemic. In addition, the choice of a theme that carries the importance of cleanliness is also significant for students. This Community Services (PkM) were attended by students from kindergarten and elementary school ages 1-3. From the analysis of the results of the PkM, the students seriously and enthusiastically took part in the activities, they could demonstrate good storytelling, and therefore could practice how to clean their faces and hands, particularly during the COVID-19 pandemic.
\end{abstract}

Keywords: COVID-19, cultural and citizenship literacy, PkM, storytelling, TPA students 


\section{PENDAHULUAN}

Sebuah lingkungan perumahan memerlukan berbagai sarana untuk memfasilitasi berbagai kegiatan. Saranasarana yang diperlukan dalam lingkungan perumahan diantaranya adalah sarana ibadah dan sarana pendidikan. Hal ini sesuai dengan UURI Nomor 4 tahun 1992 tentang Perumahan dan Pemukiman, pasal 1 Angka 6. Dalam Pasal 1 Angka 6 disebutkan bahwa "Fasilitas penunjang dimaksud dapat meliputi aspek ekonomi yang antara lain berupa bangunan perniagaan atau perbelanjaan yang tidak mencemari lingkungan, sedangkan fasilitas penunjang yang meliputi aspek sosial budaya, antara lain berupa bangunan pelayanan umum dan pemerintahan, pendidikan dan kesehatan, peribadatan, rekreasi dan olah raga, pemakaman, dan pertamanan." Berdasarkan paparan tersebut, warga perumahan Griya Bulak Asri yang berlokasi di Jalan Bulak Asri RT 004, RW 0019, Pondok Petir, Kecamatan Bojongsari, Kota Depok, Jawa Barat 16517, mengajukan pemenuhan sarana ibadah kepada pihak developer perumahan komplek tersebut. Bapak H. Ahmad Fauzi Qosim S.S., M.A., M.M., sebagai salah seorang warga pertama di perumahan tersebut mengatakan bahwa negosiasi untuk terpenuhinya hak warga menjadi sebuah perjuangan yang pada akhirnya terwujud. Setelah didirikan musala, fasilitas tersebut menjadi sarana untuk ibadah dan melaksanakan berbagai kegiatan warga dalam berbagai acara. H. Ahmad Fauzi Qosim S.S., M.A., M.M., selaku pembina musala menyampaikan bahwa berdirinya muhola tersebut adalah sebuah perjuangan yang diusahakan oleh warga untuk tersedianya fasilitas peribadatan serta media berkumpul masyarakat perumahan dan sekitarnya.

Musala yang dinamai musala Nurul Ashri ini aktif dalam berkegiatan, baik yang bersifat keagamaan ataupun kegiatan yang sifatnya umum. Kegiatan rutin yang diadakan di musala adalah kegiatan Taman Pendidikan AlQuran (TPA) untuk pengajaran baca tulis AlQuran. Peserta didik pada TPA musala Nurul Asri, datang tidak hanya dari lingkungan perumahan tetapi juga, putra putri warga yang bermukim di luar perumahan Griya Bulak Ashri. Para peserta didik berasal dari jenjang pendidikan TK, SD, dan SMP. Kegiatan TPA tersebut diadakan secara rutin pada hari Senin sampai hari Minggu. Pada hari Senin sampai Sabtu, pengajaran yang diberikan adalah baca tulis AlQuran. Sedangkan, pada hari Minggu kegiatan yang diberikan pada peserta didik TPA adalah kegiatan olahraga atau makan bersama. Kegiatan yang diadakan di hari Minggu berupa olahraga dan makan bersama tersebut adalah sebuah bentuk variasi aktivitas bagi peserta didik TPA 
agar tidak hanya mendapatkan pembelajaran baca tulis AlQuran tetapi juga menjalin keakraban individu.

Selain dari kegiatan rutin TPA, kegiatan yang diadakan di musala Nurul Ashri adalah perayaan-perayaan keagamaan rutin tahunan pada bulan Ramadhan atau pada kegiatan perayaan Islam lainnya. Kegiatan umum yang juga diadakan di musala Nurul Ashri diantaranya adalah acara kenegaraan perayaan kemerdekaan 17 Agustus 1945 dengan menggelar lomba-lomba bagi putra putri warga disekitar. Dengan demikian dapat disimpulkan bahwa kegiatan yang diadakan di musala Nurul Ashri sangat aktif dan memberikan manfaat bagi warga sekitar. Faktanya, kegiatan rutin yang diadakan baru berfokus pada kegiatan TPA dan belum ada kegiatan rutin lainnya untuk menambah wawasan peserta didik pada bidang lain. Selain itu, peserta didik berasal dari latar belakang suku, budaya, dan karakter yang berbeda-beda, sehingga menjadi perhatian khusus bagi para pembina TPA dalam memberikan pengajaran dan pembimbingan agar setiap peserta didik dapat menyatu dengan kondisi lingkungan yang heterogen. Perbedaan usia di antara para peserta didik juga menjadi salah satu kendala yang muncul dalam hal penggunaan bahasa sapaan dan pergaulan di antara peserta. Seperti misalnya peserta didik yang lebih muda menyapa peserta didik yang lebih tua tanpa menggunakan panggilan 'kak' karena merasa bahwa mereka bermain bersama. Padahal kata sapaan 'kak', 'mba', atau 'mas' adalah sapaan yang menjadi budaya bangsa untuk menunjukkan rasa hormat pada orang yang lebih tua usianya. Kata sapaan ini juga digunakan ketika berkomunikasi dan dijadikan sebagai salah satu cara bagi menghormati seseorang yang diajak berbicara dan selain itu juga ia dianggap bagi mengeratkan tali kekeluargaan dan persahabatan (Dosenpendidikan, 2021). Dalam hal ini maka diperlukan adanya pemahaman literasi budaya dan litarasi kewargaan. Berkaitan dengan hal ini, Kementrian Pendidikan dan Kebudayaan Republik Indonesia menjabarkan bahwa literasi budaya merupakan kemampuan dalam memahami dan bersikap terhadap kebudayaan Indonesia sebagai identitas bangsa. Sementara itu, literasi kewargaan adalah kemampuan dalam memahami hak dan kewajiban sebagai warga negara.

Pada Abad 21, literasi budaya dan kewargaan adalah hal yang harus dipahami dan diterapkan. Pentingnya literasi budaya dan kewargaan adalah untuk menghadapi tantangan Abad 21 yaitu: 1) menguatkan budaya lokal/ nasional dalam menghadapi kuatnya pengaruh arus budaya global; 2) berperan sebagai identitas bangsa; 3) berfungsi sebagai alat untuk menghubungkan generasi terdahulu, 
sekarang, dan masa yang akan datang. Keempat, memahami hak dan kewajiban sebagai warga negara untuk mendukung perubahan dan pembangunan Indonesia ke arah yang lebih baik. Literasi budaya dan kewargaan di keluarga, sekolah, dan masyarakat erat kaitannya dengan kearifan lokal yang ada di lingkungan tersebut (Kementrian Pendidikan dan Kebudayaan, 2021). Oleh karena itu, pengayaan bahan cerita lokal dan nasional dapat diterapkan sebagai sumber belajar bermutu untuk mencapai pemahaman literasi budaya dan kewargaan pada peserta didik TPA khususnya peserta didik pada usia kelas TK dan kelas 1-3 SD.

Pengayaan bahan cerita lokal dan nasional ini perlu diperkenalkan kepada peserta didik agar mereka mengetahui karya sastra daerah yang dilahirkan nenek moyangnya dan juga para penulis yang hidup pada masa kini. Nilai dan pesan yang bersumber dari daerahnya sendiri penting diketahui oleh setiap peserta didik. Sementara itu, bahan cerita nasional juga tidak kalah penting bagi siswa untuk mengenali keanekaragaman kisah dari berbagai penjuru tanah air. Sumber cerita nasional dapat diambil dari cerita daerah, dari daerah lain, atau cerita terkini (sastra popular) yang dihasilkan sastrawan Indonesia.

Selain itu, metode pembelajaran tatap muka tetap dipilih oleh pembina Musala
Nurul Ashri agar pembelajaran berjalan secara efektif dan menjadi kegiatan positif untuk mengisi kekosongan waktu setelah peserta didik selesai dari pembelajaran online di sekolah selama masa pandemi COVID-19 ini. Akan tetapi, penerapan kebersihan untuk penerapkan 5M (mencuci tangan, memakai masker, menjaga jarak, menjauhi kerumunan, dan mengurangi mobilitas) tetap harus dilakukan. Peserta didik harus diingatkan untuk selalu menjaga protokol 5M pada masa COVID19. Oleh karenanya, perlu adanya pengarahan khusus terutama bagi peserta didik TPA dengan tingkat TK serta SD kelas 1-3.

Berdasarkan pemaparan latar belakang permasalahan-permasalahan yang dihadapi mitra yaitu Musala Nurul Ashri tersebut, pihak dosen Universtitas Pamulang mencoba menjalin kerjasama dengan pengurus Musala Nurul Ashri untuk memberikan penyuluhan bagi peserta didik TPA. Tujuan bekerja sama dengan Musala Nurul Ashri adalah untuk memberikan pemahaman keragaman literasi budaya dan kewargaan. Hal tersebut dianggap penting agar peserta didik dapat mengetahui nilainilai budaya daerah atau lokal sehingga dapat menjaga kesantunan pergaulan dalam kehidupan yang heterogen. Sedangkan penyuluhan terhadap pentingnya penerapan protokol 5M juga akan diberikan untuk memperluas penguasaan kosa kata tentang 
menjaga kebersihan dan dapat Mendongeng sendiri merupakan kegiatan menerapkannya dalam kehidupan seharihari. Kegiatan yang akan diberikan oleh tim PkM Universitas Pamulang dirumuskan dalam kegiatan yang berjudul "Berkarya di Masa Pandemi: Dongeng Berbahasa Inggris untuk Meningkatkan Literasi Budaya dan Kewargaan”.

\section{TINJAUAN PUSTAKA}

Pandemi COVID-19 berdampak negatif terhadap berbagai sektor kehidupan termasuk pendidikan. Kondisi ini membatasi proses pembelajaran pada semua level institusi pendidikan, termasuk siswa Taman Kanak-kanak, Sekolah Dasar, dan Sekolah Menengah. Kegiatan pembelajaran yang biasanya diselenggarakan di sekolah kemudian harus dilaksanakan dari rumah masing-masing. Fenomenanya, tenaga pendidik dan siswa tidak dapat memaksimalkan materi dan keterampilan dalam pembelajaran sebagaimana mestinya. Demikian juga dengan keterampilan literasi budaya dan kewargaan yang biasanya dipelajari di sekolah tidak dapat terlaksana dengan maksimal di masa pandemi melalui pembelajaran jarak jauh. Oleh karena itu, siswa perlu mendapatkan literasi budaya kewargaan dari pembelajaran informal.

Pendidikan literasi budaya dan kewargaan yang dilakukan secara informal dapat berupa kegiatan mendongeng. yang sangat dekat dengan anak-anak dan dapat dilakukan sambil berkreasi dan belajar. Kegiatan ini bertujuan tidak hanya sebagai solusi pembelajaran literasi budaya dan kewargaan akan tetapi juga untuk menstimulasi kreativitas pendidik dan siswa dalam menghasilkan karya. Mendongeng dapat menjadi media pembelajaran literasi budaya dan kewargaan serta pendidikan mengenai pentingnya kebersihan dalam kehidupan sehari-hari khususnya pada masa pandemi. Singkatnya, mendongeng dapat menjadi kegiatan pembelajaran yang menarik karena melatih beragam literasi, kreativitas, dan nilai-nilai penting lainnya seperti kebersihan dan kebersamaan (Wahyuni et al., 2021).

\section{A. Mendongeng (Storytelling)}

Mendongeng merupakan kegiatan yang telah berkembang sejak zaman dahulu kala dan menjadi tradisi bagi masyarakat Indonesia sejak berabad yang lalu. Kegiatan mendongeng berawal dari lingkungan keluarga dimana para orang tua bercerita kepada anak-anaknya tentang kisah-kisah yang berisikan pesan moral dan pesan yang berguna dalam hidup bersosialisasi dalam masyarakat. Cerita dongeng ini biasanya disajikan pada pagi atau malam hari saat seluruh anggota keluarga berkumpul. Dongeng juga 
dituturkan semenjak usia dini saat menjelang tidur yang dikenal dengan dongeng penghantar tidur. Kegiatan mendongeng tidak hanya ditujukan bagi anak-anak usia dini namun juga anak-anak usia pra remaja bahkan remaja. Mendongeng sendiri dapat membantu terbentuknya karakter anak atau pendengar dongeng. Dongeng yang disampaikan menjelang tidur dapat mempengaruhi pola pikir dan sikap anak terkait dengan isi cerita dan tujuan bercerita atau mendongeng.

Dongeng memiliki definisi yang sangat jelas terkait sumber cerita dan bagaimana dongeng tersebut dituturkan sebagaiman yang disampaikan oleh Azis (2015) dan dikutip oleh Ria (2018, p. 69), "Dongeng adalah cerita rakyat yang secara lisan turun-temurun disampaikan kepada kita, pengarangnya tidak dikenal, berada pada dunia khayalan, tidak jelas mengenai tempat dan waktunya, kemudian ditulis oleh penulis atau pengarang berbudaya untuk kalangan berbudaya pula." Dongeng sebagai karya sastra tidak harus dipelajari melalui pendekatan sastra saja namun juga melalui tujuan dan pendidikan apa yang terkait pada dongeng tersebut (Latifah et al., 2021). Dongeng diceritakan bertujuan memberi hiburan bagi pendengarnya, menariknya banyak dongeng yang mengandung unsur pendidikan karakter, moral dan kebenaran. Dongeng yang mengandung unsur pendidikan merupakan sarana bagi para guru untuk menyampaikan pelajaran dan membentuk kepribadian siswa yang mendengarnya. Seperti yang disampaikan oleh Suyatno dan Abas (2001) dan dikutip oleh Utomo (2013, p. 2) "Cerita dapat digunakan oleh orang tua dan guru sebagai sarana mendidik dan membentuk kepribadian anak melalui pendekatan transmisi budaya atau cultural transmission approach."

Dongeng pada masa pandemi COVID-19 ini dapat diberikan untuk memberikan penyuluhan kepada masyarakat terutama anak-anak tentang pentingnya menjaga kebersihan diri dan lingkungan serta kesehatan pribadi. Dongeng dapat diberikan dengan melukiskan cerita tentang bagaimana menjaga kebersihan dan pentingnya menjaga jarak dalam masa pandemi. Melalui dongeng orang tua dan guru juga dapat mengembangkan kemampuan literasi dan emosi anak. Menurut Diana (2018), melalui dongeng atau cerita manfaat yang diperoleh anak ataupun peserta didik adalah mengembangkan daya imajinasi, menambah kosa kata anak, membentuk perkembangan sosial dan emosional serta memperkuat hubungan antara yang mendongeng dan mendengarkan dongeng. Hal ini didukung oleh pendapat Utomo (2013, p. 5) yang menyatakan bahwa cerita dapat menjadi sarana penuntun perilaku yang baik, kritik yang halus (tidak 
menyakitkan hati) agar terbentuk pola norma dan perilaku halus dan baik.

Pada kegiatan Pengabdian kepada Masyarakat di Musala Nurul Ikhlas, anakanak usia TK dan SD tidak hanya diperdengarkan cerita atau dongeng melainkan juga diajarkan bagaimana bercerita atau mendongeng yang ceritanya disesuaikan dengan usia dan kemampuan literasi mereka. Menurut Brown \& Yule (1996), sebagaimana yang dikutip oleh Zein "semakin pandai seseorang bercerita semakin kuat pengaruh kata-kata tersebut pada anak serta dapat melibatkan anak secara langsung merencanakan ujaran tertentu ataupun mengoreksi ujaran yang keliru" (2015, p.156). Hal penting yang perlu diperhatikan dalam mendongeng tidak hanya cerita yang menarik namun juga memiliki pesan tertentu yang bermanfaat bagi anak-anak yang mendengarkannya. Dalam hal ini cerita yang dipilih adalah cerita yang menggambarkan bagaimana pentingnya menjaga kebersihan diri dan bagaimana menjaga kebersihan diri dan lingkungan yang akan memberikan dampak yang baik bagi kesehatan.

Anak-anak tidak hanya diajak untuk mendongeng melainkan juga memahami masing-masing karakter dari dongeng yang diceritakan. Mereka juga diajak bekerjasama untuk mempersiapkan wayang atau boneka kertas yang digunakan dalam mendongeng. Hal ini bertujuan untuk merangsang kreatifitas anak dan daya nalarnya serta jiwa seni dalam mempersiapkan wayang atau boneka kertas untuk mendongeng. Mereka juga diarahkan untuk mampu berkomunikasi dan bekerjasama dengan rekan sebayanya. Kegiatan bercerita diarahkan agar anakanak dapat mengenal Bahasa Inggris dan menambah kosakata dalam Bahasa Inggris.

Kegiatan mendongeng yang dilaksanakan di Musala Nurul Ashri diharapkan dapat merangsang minat anakanak untuk belajar Bahasa Inggris. Selain itu juga mengajak mereka untuk hidup bersih dan menjaga kebersihan diri dan lingkungan. Kegiatan ini juga bertujuan untuk menanamkan rasa cinta pada karya sastra terutama cerita rakyat dan juga memahami keragaman budaya yang ada.

\section{B. Literasi Budaya dan Kewargaan}

Perkembangan teknologi komunikasi merupaka sebuah kemajuan dizaman ini dimana segala informasi dapat diakses dengan mudah dan cepat. Perkembangan teknologi informasi secara maya atau melalui internet membuka arus informasi secar global baik secara nasional maupun internasional. Hal ini memberi kemudahan bagi pemerolehan informasi yang berguna bagi pendidikan dan perkembangan ilmu pengetahuan, namun juga memberikan dampak negatif. Dampak negatif antara lain 
terjadinya disinformasi terutama karena sangat mudahnya menyebarkan dan membuat berita termasuk berita yang tidak benar atau fake news maka hal ini dapat menimbulkan terjadinya disinformasi. Disinformasi bisa terjadi karena kurang hati-hati dalam mencerna sebuah berita atau kurang cerdasnya dalam menyikapi sebuah konten berita yang ada pada media online. Oleh karena itu diperlukan adanya kemampuan litarasi yang baik.

Kemampuan litarasi tidak hanya terbatas pada kemampuan baca tulis saja namun juga pada kemampuan melek teknologi informasi. "Literasi tidak hanya sekadar kemampuan membaca dan menulis, tetapi literasi bisa berarti melek teknologi, politik, berpikir kritis, dan peka terhadap lingkungan sekitar (Irianto \& Febrianti, 2017 dikutip dari Pratiwi \& Asyarotin, 2019, p.67). Terkait hal tersebut, Kementerian Kebudayaan menyatakan pentingnya memiliki keterampilan literasi budaya dan kewargaan di mana masyarakat menyadari pentingnya bersikap sebagai bagian dari suatu budaya melalui pendidikan literasi. Literasi budaya merupakan:

"Kemampuan dalam memahami dan bersikap terhadap kebudayaan Indonesia sebagai identitas bangsa, sementara literasi kewargaan adalah kemampuan dalam memahami hak dan kewajiban sebagai warga negara. Dengan demikian, literasi budaya dan kewargaan merupakan kemampuan individu dan masyarakat dalam bersikap terhadap lingkungan sosialnya sebagai bagian dari suatu budaya dan bangsa" (Kementrian Pendidikan dan Kebudayaan, 2017)

Literasi budaya dan kewargaan merupakan hal yang penting untuk diberikan dan ditanamkan pada seluruh warga negara Indonesia mulai dari usia kanak-kanak. Selain itu juga penting bagi genarasi milenial agar mereka dapat mencintai dan ikut melestarikan kebudayan Nasional. Literasi budaya tidak hanya dimulai pada saat anak-anak memasuki jenjang pendidikan namun dimulai dari lingkungan keluarga. Menurut Tama dan Oktaviani (2019), kemampuan literasi tidak hanya terkait pada intelegensia, kondisi fisik, kesehatan fisik, lingkungan, perbedaan status sosial keluarga termasuk di dalamnya keterlibatan orang tua. Berdasarkan hal tersebut maka literasi budaya sebaiknya diperkenalkan mulai dari lingkungan keluarga dan juga lingkungan sekitar keluarga seperti rukun tangga (RT) dan juga rukun warga (RW).

Kegiatan pengabdian masyarakat yang dilakukan di Musala Nurul Ashri, tidak hanya mengajak anak-anak untuk mengenal dan mempraktekkan hidup bersih dimasa pandemi COVID-19 naun juga memperkenalkan keragaman budaya yang ada ditanah air. Karakter atau tokoh yang 
ada di dalam cerita juga ikut memperkenalkan karakter baik yang harus diadopsi oleh anak-anak peserta kegiatan pengabdian kepada masyarakat. Meskipun dongeng atau cerita yang digunakan menggunakan Bahasa Inggris, namun nilai moral dan karakter yang tergambar didalamnya tidak bertentangan dengan budaya di Indonesia.

\section{METODE PELAKSANAAN}

Kegiatan Pengabdian kepada Masyarakat ini akan diselenggarakan sebagai salah satu perwujudan Tri Darma Perguruan Tinggi yaitu mengaplikasikan ilmu untuk meningkatkan kesejahteraan masyarakat sekitar. Dalam hal ini, tim PkM Prodi Sastra Inggris Universitas Pamulang mengamati adanya kebutuhan aktifitas pendidikan informal di Taman Pendidikan AlQuran (TPA) Nurul Ashri, Pondok PetirDepok selama pandemi. Integrasi Perguruan Tinggi dan masyarakat yang dapat dilakukan dalam menciptakan aktifitas pendidikan informal di antaranya adalah Gerakan Literasi Nasional yang digagas tahun 2017 oleh Kementrian Pendidikan dan Kebudayaan, yaitu perlunya membangun budaya literasi pada seluruh ranah pendidikan (keluarga, sekolah, dan masyarakat). Dari enam literasi dasar: literasi baca tulis, literasi numerasi, literasi sains, literasi digital, literasi finansial, dan literasi budaya dan kewargaan, fokus literasi dasar yang dipilih dalam kegiatan PkM ini adalah literasi budaya dan kewargaan dengan judul kegiatan "Berkarya di Masa Pandemi: Dongeng Berbahasa Inggris untuk Meningkatkan Literasi Budaya dan Kewargaan”. Kegiatan ini bertujuan untuk membentuk karakter siswa yang mengetahui, memahami, menghargai, menghormati, serta melestarikan keragaman budaya demi menciptakan kesatuan bangsa. Adapun kegiatan PkM ini akan dilakukan dalam tiga tahapan yaitu: persiapan, pelaksanaan, dan pelaporan dengan susunan jadwal kegiatan sebagai berikut:

Pada tahap persiapan, tim PkM melakukan penjajakan analisis situasi dengan pihak mitra TPA Nurul Ashri Pondok Petir-Depok dan mengajukan proposal kegiatan ke LPPM Universitas Pamulang. Tahapan ini dilakukan dengan empat rincian kegiatan yaitu: 1) diskusi dengan penanggung jawab mitra pada minggu pertama September, 2) korespondensi dengan mitra kegiatan PkM pada minggu kedua September, 3) penyusunan proposal pada minggu ketiga dan keempat September, dan 4) pengajuan proposal PkM pada minggu pertama Oktober.

Pada tahap pelaksanaan, tim PkM melakukan tiga kegiatan. Yang petama, persiapan kegiatan penyuluhan dilakukan 
sejak minggu pertama Oktober sampai minggu ketiga Oktober yaitu: membuat banner kegiatan PkM, mencetak poster materi literasi budaya dan kewargaan, menulis skrip dongeng sesuai tema kegiatan PkM, membuat wayang kertas sebagai properti dongeng. Yang kedua, pelaksanaan kegiatan penyuluhan dengan mitra PkM pada minggu keempat Oktober yaitu: pementasan dongeng oleh mahasiswa Sastra Inggris Universitas Pamulang, penyuluhan literasi budaya dan kewargaan kepada peserta didik mitra, dan pementasan dongeng oleh peserta PkM. Yang ketiga, tindak lanjut kegiatan penyuluhan pada minggu pertama November yaitu: evaluasi kegiatan dengan mitra. Kegiatan ini perlu dilakukan demi perbaikan pelaksanaan PkM periode selanjutnya baik di mitra yang sama maupun di mitra berbeda.

Pada tahap pelaporan, tiga kegiatan yang dilakukan oleh tim PkM yaitu: 1) pembuatan laporan $\mathrm{PkM}$ pada minggu kedua dan minggu ketiga November, 2) penyerahan laporan kegiatan $\mathrm{PkM}$ ke LPPM Universitas Pamulang pada minggu keempat November, dan 3) publikasi kegiatan $\mathrm{PkM}$ (media sosial dan jurnal ilmiah).

\section{HASIL DAN PEMBAHSAN}

Kegiatan PkM yang dilaksanakan selama tiga hari yaitu pada tanggal $29-30$ Oktober 2021 bertempat di Musala Nurul
Ashri Jalan Bulak Asri, Pondok Petir, Kecamatan Bojongsari, Kota Depok, Jawa Barat 16517, telah selesai dilaksanakan berdasarkan tujuan dan agenda yang telah dipaparkan dalam proposal kegiatan. PkM yang bertema "Berkarya di Masa Pandemi: Dongeng Berbahasa Inggris untuk Meningkatkan Literasi Budaya dan Kewargaan" ini dilakukan secara tatap muka terbatas. Jumlah peserta yang mengikuti kegiatan PkM berjumlah 25 orang. Materi PkM disampaikan melalui teknik story telling dengan menggunakan media boneka kertas. Boneka-boneka kertas tersebut dibuat dalam berbagai karakter yang mengusung keberagaman budaya. Kegiatan inti dibuka dengan menampilkan pementasan cerita yang dilakukan oleh para mahasiswa. Setelah peserta menyaksikan pementasan cerita yang dilakukan oleh para mahasiswa, masing-masing peserta diberikan boneka kertas dengan karakter daerah yang berbeda-beda. Lalu, peserta dibagi ke dalam kelompok berdasarkan karakter boneka kertas yang mereka pilih dan diminta untuk mewarnai boneka kertas tersebut. Selanjutnya, peserta berlatih memperkenalkan diri menggunakan Bahasa Inggris. Sebagai kegiatan ice breaking, ditampilkan lagu dalam bahasa Inggris yang bertema kebersihan diri dan peserta diminta untuk ikut bernyanyi. Pada akhir kegiatan inti, masing-masing peserta 
diminta melakukan perkenalan diri dengan menggunakan boneka kertas yang telah mereka warnai.

Hasil kegiatan PkM menargetkan tercapainya: 1. jumlah peserta 2. tujuan pelaksanaan kegiatan 3. materi yang telah direncanakan, dan 4. kemampuan peserta dalam memahami materi. Target pertama adalah capaian jumlah peserta yaitu 20 anak. Namun pada pelaksanaanya, kegiatan PkM dihadiri oleh 25 peserta. Hal ini menunjukkan bahwa target peserta tercapai dengan baik karena melebihi jumlah yang ditargetkan diawal kegiatan. Target kedua yaitu tercapainya tujuan pelaksanaan kegiatan yang mencakup peningkatkan kesadaran siswa TK dan SD akan pentingnya menjalin pertemanan dan persaudaraan dan bekerjasama tanpa memandang perbedaan. Kegiatan mendongeng juga bertujuan untuk menumbuh kembangkan kesadaran akan kewargaan sebagai warga negara Republik Indonesia yang terdiri dari banyak suku dan bahasa daerah. Tujuan lainnya adalah menumbuhkan kesadaran akan pentingnya menjaga kebersihan diri dan lingkungan sebagai warga negara yang baik didalam wilayah Republik Indonesia terutama di masa pandemi COVID-19 saat ini. Berdasarkan berlangsungnya kegiatan PkM, dapat dilihat bahwa peserta dapat menjalin kerjasama dalam kelompoknya serta memahami dan menerapkan kebersihan diri selama berlangsungnya kegiatan.

Target ketiga yaitu tercapainya materi yang telah direncanakan. Semua materi yang betema keberagaman dan kebersihan telah dirancang dalam sebuah cerita pertemanan sekelompok anak yang berasal dari berbagai daerah. Alur cerita tersebut dapat disampaikan dari awal sampai akhir dengan menggunakan media boneka wayang pada saat kegiatan $\mathrm{PkM}$ sesuai dengan durasi waktu yang telah ditentukan. Dengan tersampaikan materi kegiatan secara keseluruhan dan melihat respon peserta yang bersemangat mendengarkan dongeng, maka dapat dikatakan tujuan materi tercapai sesuai rencana.

Target kegiatan yang terakhir yaitu kemampuan peserta dalam memahami materi. Materi disampaikan dengan rangkaian kegiatan yaitu mendengarkan dongeng, berkreasi dengan mewarnai boneka kertas, serta berlatih dan tampil untuk memperkenalkan diri dengan karakter boneka kertas yang berbeda-beda. Rangkaian kegiatan tersebut diikuti oleh semua peserta dengan antusias. Semua peserta bersemangat untuk tampil kedepan memperkenalkan diri dengan menggunakan media boneka kertas yang mereka miliki.

Secara singkat, semua target capaian PkM yang dirumuskan berdasarkan harapan mitra yaitu menyatukan 
keberagaman peserta yang berbeda tingkatan usia dan suku, meningkatkan kreatifitas melalui kegiatan belajar yang menarik, menambah wawasan, dan meningkatkan keterampilan berbahasa Inggris dapat dicapai dengan baik.

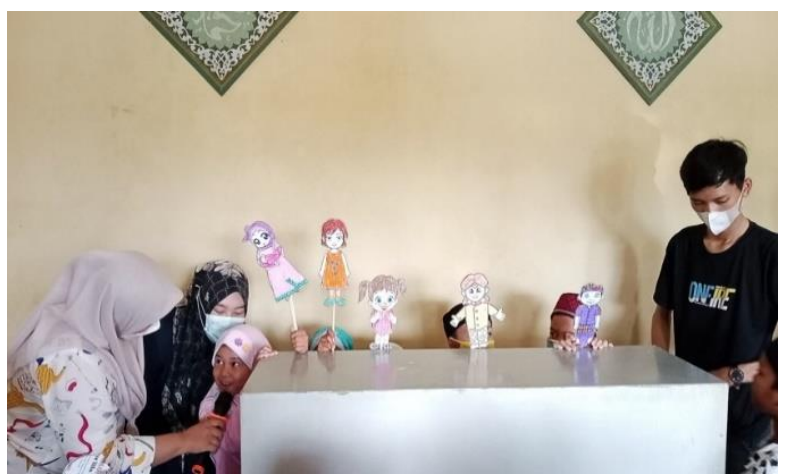

Gambar 1. Praktek Mendongeng Peserta Didik

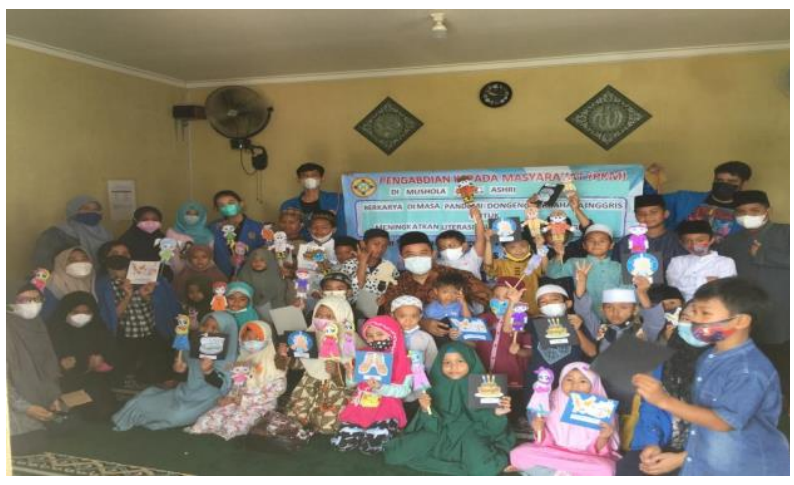

Gambar 2. Tim PkM dan Peserta

\section{KESIMPULAN DAN SARAN}

Kegiatan Pengabdian kepada

Masyarakat dengan tema "Berkarya pada

Masa Pandemi: Dongeng Berbahasa Inggris untuk Meningkatkan Literasi Budaya dan Kewargaan" telah dilaksanakan secara luring dengan jumlah peserta didik yang terbatas. Pembatasan ini dilakukan karena masih dalam situasi pandemi COVID-19 sehingga tidak memungkinkan untuk melaksanakan kegiatan dengan jumlah siswa lebih dari 25 orang.

Kegiatan yang dilakukan adalah mendongeng dengan menggunakan alat bantu berupa wayang yang dikreasikan sehingga dapat menarik minat peserta didik. Tema mendongeng adalah perayaan ulang tahun oleh beberapa karakter dengan latar budaya yang berbeda di Indonesia. Mereka merayakan serangkaian kegiatan ulang tahun dan tetap memperhatikan kebersihan diri. Kegiatan PkM diawali dengan mendongeng yang dilakukan oleh mahasiswa Universitas Pamulang yang diselingi dengan kegiatan bernyanyi bersama. Kemudian dilanjutkan dengan mewarnai wayang yang telah disiapkan. Kegiatan PkM ditutup dengan mendongeng yang dilakukan oleh para peserta didik.

Dari kegiatan dan asesmen yang telah dilaksanakan, maka dapat disimpulkan bahwa tujuan kegiatan telah tercapai antara lain: 1) jumlah peserta didik 25 orang yang sesuai dengan target yang ditetapkan untuk pertemuan terbatas dimasa COVID-19, 2) meningkatkan kesadaran peserta didik terhadap pentingnya menjalin pertemanan dan persaudaraan dan bekerjasama tanpa 
memandang perbedaan, 3) menumbuhkan kesadaran terhadap pentingnya menjaga kebersihan diri dan lingkungan sebagai warga negara Indonesia yang baik terutama pada masa pandemi COVID-19, 4) meningkatkan pemahaman peserta didik mengenai memahami sekaligus mempraktikkan dengan baik materi yang disampaikan.

Untuk pelaksanaan kegiatan PkM selanjutnya, pelaksana diharapkan dapat menggunakan teknik ataupun strategi yang berbeda dengan media yang disesuaikan dengan usia dan tujuan PkM. Selain itu, tujuan PkM sebaiknya tidak hanya memotivasi anak untuk belajar namun juga berkreasi dalam kegiatan pembelajaran dan kehidupan mereka.

\section{DAFTAR PUSTAKA}

Diana, A. (2021, October 13). Manfaat mendongeng bagi perkembangan otak dan emosi anak. Popmama. https://www.popmama.com/kid/4-5years-old/astri-diana/manfaatmendongeng-bagi-perkembanganotak-dan-emosi-anak/4

Dosenpendidikan. (2021, August 10). Kata sapaan.https://www.dosenpendidika n.co.id/kata-sapaan/

Kementrian Pendidikan dan Kebudayaan. (2021). Modul literasi budaya dan kewargaan. http://ditpsd.kemdikbud.go.id/upload /filemanager/2021/06/6\%20Modul\% 20Literasi\%20Budaya $\% 20$ dan $\% 20 \mathrm{~K}$ ewargaan.pdf
Kementrian Pendidikan dan Kebudayaan. (2017). Materi pendukung literasi budaya dan kewargaan: Gerakan literasi nasional.

https://gln.kemdikbud.go.id/glnsite/ wp-content/uploads/2017/10/literasiBUDAYA-DANKEWARGAAN.pdf

Latifah, Anggraini, I. D., Sariasih, W., \& Perlina, M. (2021). Mendongeng digital sebagai media peningkatan soft skill santri sanggar baca jendela dunia. Acitya Bhakti, 1(2), 125-133. http://openjournal.unpam.ac.id/index .php/ACB/article/view/10868

Pratiwi, A., \& Asyarotin, E. N. K. (2019). Implementasi literasi budaya dan kewargaan sebagai solusi disinformasi pada generasi millennial di Indonesia. Jurnal Kajian Informasi \& Perpustakaan, 7(1), 65-80.

http://jurnal.unpad.ac.id/jkip/article/ view/20066

Tresnasih, R. I. (2018). Tradisi mendongeng sebagai upaya pembudayaan nilai-nilai dalam keluarga di kelurahan cisaran wetan kecamatan cinambo kota bandung. Journal Patanjala, 10(1), 67-82. https://www.neliti.com/id/publicatio ns/292005/tradisi-mendongengsebagai-upaya-pembudayaan-nilainilai-dalam-keluarga-di-kelur

Tarma, \& Oktaviani, M.(2019). Literasi budaya dalam keluarga pada masyarakat sekitar candi batujaya: Perspektif sosial ekonomi. Konferensi Nasional Ilmu Administarsi Literasi Budaya Dalam Keluarga Pada Masyarakat Sekitar ... http://180.250.247.102 > article > download > pdf

Utomo, S. B. (2013). Mendongeng dalam perspektif pendidikan. Jurnal 
Agastya, 3(1). http://ejournal.unipma.ac.id/index.php/JA/a rticle/view/901

Wahyuni, Y. Tisnawijaya, C., Haryati, Suhayati, L., \& Prayuana, R. (2021). Dongeng: Media pemahaman multibudaya bagi generasi penduduk global. Acitya Bhakti, 1(1), 83-90. http://www.openjournal.unpam.ac.id /index.php/ACB/article/view/9136
Zein, R. (2015). Implementasi "Developmentally Approach Practice" Pada Kegiatan Bercerita dalam Pembelajaran Anak TK. ejournal.stkip-pgrisumbar.ac.id/index.php/pelangi http://dx.doi.org/10.22202/jp.2015.v $7 \mathrm{i} 2.197$ 